\title{
The Relationship Between Knowledge and Perception of the People of Melaka on The Concept of Sufi Order
}

Nur Afifah Fadzil, Mohammad Fahmi Abdul Hamid, Muhammad Dzarif Ahmad Zahidi, Ahmad Nurilakmal Norbit \& Abdul Muhaimin Abu Bakar

To Link this Article: http://dx.doi.org/10.6007/IJARBSS/v11-i9/10845 DOI:10.6007/IJARBSS/v11-i9/10845

Received: 07 July 2021, Revised: 28 July 2021, Accepted: 19 August 2021

Published Online: 24 September 2021

In-Text Citation: (Fadzil et al., 2021)

To Cite this Article: Fadzil, N. A., Hamid, M. F. A., Zahidi, M. D. A., Norbit, A. N., \& Bakar, A. M. A. (2021). The Relationship Between Knowledge and Perception of the People of Melaka on The Concept of Sufi Order. International Journal of Academic Research in Business and Social Science, 11(9), 1652-1659.

Copyright: (c) 2021 The Author(s)

Published by Human Resource Management Academic Research Society (www.hrmars.com)

This article is published under the Creative Commons Attribution (CC BY 4.0) license. Anyone may reproduce, distribute, translate and create derivative works of this article (for both commercial and non-commercial purposes), subject to full attribution to the original publication and authors. The full terms of this license may be seen at: http://creativecommons.org/licences/by/4.0/legalcode

Vol. 11, No. 9, 2021, Pg. 1652 - 1659

Full Terms \& Conditions of access and use can be found at http://hrmars.com/index.php/pages/detail/publication-ethics 


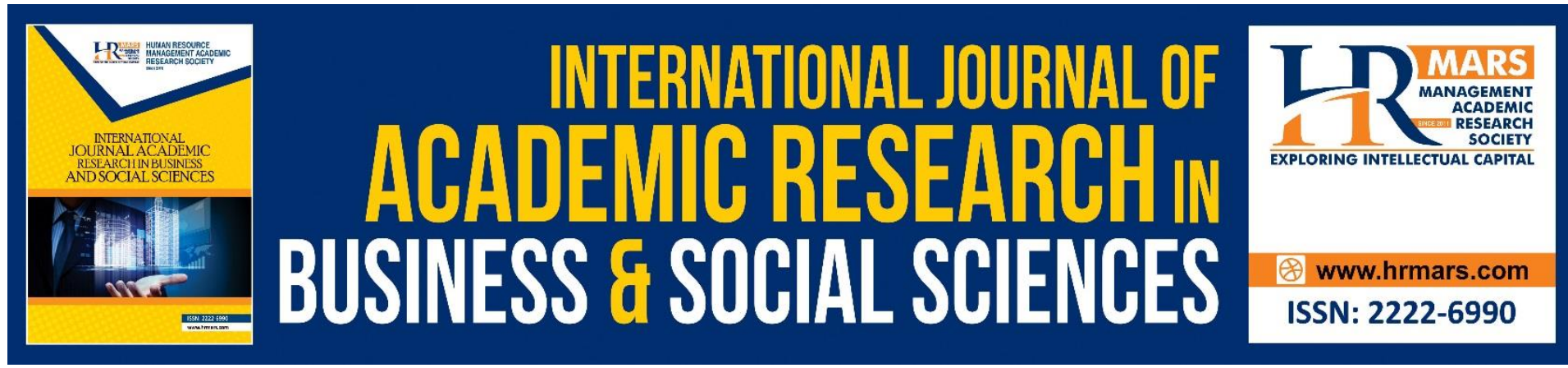

\title{
The Relationship Between Knowledge and Perception of the People of Melaka on The Concept of Sufi Order
}

\author{
Nur Afifah Fadzil', Mohammad Fahmi Abdul Hamid², \\ Muhammad Dzarif Ahmad Zahidi ${ }^{1}$, Ahmad Nurilakmal Norbit ${ }^{1}$ \& \\ Abdul Muhaimin Abu Bakar ${ }^{1}$ \\ ${ }^{1}$ Faculty of Language \& Education, Kolej Universiti Islam Melaka, Malaysia, ${ }^{2}$ Academy of \\ Contemporary Islamic Studies, Universiti Teknologi Mara, Melaka, Malaysia \\ Email: nurafifahfadzil@kuim.edu.my
}

\begin{abstract}
This study aims to identify the relationship between the level of knowledge and perception of the people of Melaka on the concept of Sufi order. This study was conducted on the community around Melaka with the involvement of 385 respondents. This study uses quantitative methods and questionnaire to obtain data related to the level of knowledge and perception on the concept of Sufi order. Correlation analysis was used to determine the relationship between the level of knowledge and perception of the people of Melaka towards the Sufi order. There was a significant positive and strong relationship between knowledge and perception of the concept of Sufi order $(r=0.676, p<0.01)$. The average score for respondents' level of knowledge of the Sufi order was at a moderate level $(M=3.627, S P=$ 1.190). While the perception of the Sufi order on average score was at a high level $(M=4.221$, $\mathrm{SP}=0.628$ ). The findings show that the knowledge and perception of the people of Melaka about the Sufi order is at a good level. However, improvement in terms of teaching and exposure related to the Sufi order is needed to elevate it to a higher level.
\end{abstract}

Keywords: Knowledge, Perception, Order, Sufi, The People of Melaka

\section{Introduction}

Tarekat and tasawuf are two different words but have almost the same meaning. When tasawuf is mentioned, it is undeniable to have debate on tarekat because, in the discipline of tasawuf, tarekat is a pillar of tasawuf (Sidek, 2016). Al-Nadwi (1987) stated that the knowledge of Sufism is more appropriately called the knowledge of Ihsan or Tazkiyah or Fiqhul Batin because the knowledge educates and purifies the human soul and then leads to the perfection of faith. To achieve that goal, the practitioners of Sufi order have to overcome various obstacles in increasing the level of spirituality of self (Al-Jurjani, 1985). Sufism is a field of knowledge that brings together the ideas of spiritual, while the institution of tarekat is an organization related to the implementation of all the ideas of spiritual contained in the 
knowledge of Sufism. Sufism and the institution of tarekat are two elements that play a huge role in Islam.

The history of the formation of the tarekat institution began in year of the fifth and sixth Hijrah according to Islam calendar. Before the existence of the institution of tarekat, in the third and fourth centuries, the practice of Sufism was more towards following the spiritual example of Rasulullah SAW as the main example. After that, in the fifth and sixth centuries of the Hijrah, Sufism was developed into a practical system. Beginning that phase, the institution of tarekat has emerged and formed as an organization in an effort to practice Sufism in a more practical way (Riyadi, 2014).

The discipline of Sufi order is one of the ways to purify the morals and development of the identity of the Muslims which is widely practices in the life of the Muslim community. The teaching of Sufi order has been compiled in a systematic and structured form as early as the third century aimed at forming piousness in human beings, despite the fact that it has existed since the early days of Islam as one of the means of appreciating Islamic teachings (Faudzinaim, 2016).

For the Malaysian Muslim community in general, the term Sufi order is not something unfamiliar since it is known by various names based on its source. The entry of Sufi order is in line with the entry of Islam in Malaysia has brought a dimension of spiritual power among the Malay community formerly (Azlin \& Badaruddin, 2019). Looking at the development of the order of Sufi in Malaysia, there are three phases can be summarized which are first, in the early Islamic empire and colonization, second is the time after the independence of Malaya, and the third is in the era of globalization (Harun, 2015). However, the development of the tarekat is not enclosed to all states in Malaysia because there are certain challenges that affect its development (Azlin \& Badaruddin, 2019). In Malaysia, there are 15 tarekat namely Naqsyabandiyah, Ahmadiyah, Qadiriyah, Qadiriyah Naqsyabandiyah, Syatiriyyah, Alawiyah, Shammaniyah, Aiderusiyah, Mufradiyah, Suhrawardiyah, Rifa'iyah, Darqawiyah, Khalwatiyah, Shadhiliyah and Sanusiyah (Hamdan, 1990).

\section{The Concept of Sufi Order}

Sufi order is one of the disciplines in Islam. However, these two terms are different but have almost the same meaning. Looking at the emergence of the term Sufism, it never existed in the time of the Prophet SAW, Companions and the time of Tabi'in, the term only appeared in the second century of Hijrah (al-Qusyairi, 1921) and some argue it appeared in the third century of Hijrah (Harun, 2015). However, this discipline has existed in the time of the Prophet SAW which during that time this discipline of knowledge was not given a specific name and not discussed in detail as it exists after the time of the Prophet SAW until now (al-Taftazani, 1996).

Various opinions given by scholars on the emergence of the term of Sufism. The original source of the word Sufism is divided into two sources, first, Sufism derived from the word Sufi which comes from Greece and secondly al-Suffah, al-Safa, al-Sifah, al-Saff, alSufanah, Sufah al-Qafa, al-Sufah, and al-Suf which are all from Arabic. However, among all these opinions, the word tasawuf is taken from the word al-Suf which refers to clothes made of goat hair (Ishak, 1993). The word al-Suf is appropriate from the point of view of the Arabic method, al-Suf means becomes a Sufi and nothing else (Hilmi, 1996). This knowledge refers to the method of appreciating Ihsan as the Prophet SAW's answer to Jibril related to the question about Ihsan, that is "You worship Allah, as if you see Him. If you cannot see Him, rest assured that He always sees you (Rosman, et.al., 2021). 
The discipline of Sufism also refers to knowledge related to morality to form individual character to live in manner to Allah SWT, humankind and nature. This is based on the opinion of scholars who present ijtihad tarbiyyah ruhiyyah by presenting the understanding of the three questions of Jibril to the Prophet SAW about Iman, Islam and Ihsan with reference to Iman related to Tauhid, Islam related to Fiqh and Ihsan related to Sufism. The practice of these three elements in daily life in order to enhance the appreciation of faith and strengthen the relationship of a servant to Allah SWT to achieve makrifatullah that is to be a servant who truly knows Allah SWT. To achieve makrifatullah, the scholars of Sufism associate it with the path of tarekat (Rosman, et.al., 2021).

Regarding the origin and source of the teachings of Sufism, there are two opinions explaining this matter, the first opinion says that the teachings of Sufism come from Islam based on the Qur'an and Sunnah because in the Qur'an there are a number of verses that explain the essence of the teachings of Sufism (Nasution, 2007) and so there are hadith explain the practice of Ihsan which is a solid prove explaining the teachings of Sufism derived from Islamic teachings (Hafiun, 2012). Not only that, this discipline of Sufism can also be seen in the practical lives of the companions and subsequent generations (As-Syarqawi, 2003). There are many verses of the Qur'an that encourage people to practice a life based on Sufism, including the verse that commands people to always purify their souls which is found in surah as-Syams verse 9, a verse that explains the afterlife is better than the life of this world as in surah al-An 'am verse 32, a verse that explains the characteristics of a religious and pious person as in surah al-Ahzab verse 35 and so on. The teachings mentioned in the verses of the Qur'an above are the main elements of a Muslim in the practice of Sufism (Sulaiman, 2015).

While the second opinion considers the teachings of Sufism are not derived from Islam. This opinion is from orientalists such as Ignas Goldziher and Reynold Nicholson. Ignas Goldziher argues that the teachings of Sufism contained in the Qur'an are the result of the processing of other religious ideologies and beliefs (Nasution, 2008). Reynold Nicholson also claimed that the teachings of Sufism came from religions other than Islam. He gave the example of clothes worn by Sufis made of goat hair derived from the Christian tradition (alTaftazani, 1996). There are also arguments about the teachings of Sufism originated in Hinduism, Buddhism and Persia, and this is also a fact that needs to be corrected as Hinduism and Buddhism did not flourish in Arab lands. Similarly, the life of the Persian community is greatly influenced by Arab culture (Hafiun, 2012).

Regarding the discussion of the division of Sufism, there are three types of Sufism, namely moral Sufism, philosophical Sufism and practical Sufism. This shows that Sufism is a very broad field in Islam. Although divided into three types, the implementations of each type are closely related. All three are integrated in solving the problems of divinity and human psyche so as to bring positive effects for human life and nature (Bakri, 2019).

Regarding moral Sufism, it is the process of shaping human morality to achieve the purity of the soul towards the optimal happiness of life. Next is the philosophical Sufism which is a discussion of the fusion between intuitive vision and rational vision. In philosophical Sufism, the term philosophy which is often used has influenced the views or thoughts of Sufi figures, but the originality of the field of Sufism still remains. Based on this, philosophical Sufism cannot be considered as philosophy because its methods and teachings are based on dhauq which is feelings or experience (Syukur, 2002).

Apart from that, the discussion of practical Sufism is related to the practice of Sufism in the form of spiritual practice to get closer to Allah SWT. This spiritual practice is a continuation of moral education. A person who wants to practice the practical Sufism needs 
to take a specific path in order to lead to Allah SWT and this is also known as the path of tarekat (Syukur, 2002). Tarekat is a specific spiritual path for people who walk towards Allah SWT and need to go through various obstacles and through spiritual improvement in various phase (al-Jurjani, 1985).

Meanwhile, a clearer explanation regarding the tarekat is as stated by Sheikh Najm alDin (Al-Hasan, t.t). He explained that tarekat is to do taqwa and things that can bring one closer to Allah and through various obstacles and phase. Looking at the two definitions related to tarekat, they are almost identical. However, the opinion of sheikh Najm al-Din explains the position and relationship of the tarekat with the Syariah and Hakikat. It can be understood through his opinion that the syariah is to enslave oneself to Allah, tarekat is a way of presenting Allah in the heart and Hakikat is to witness Allah with the eyes of the heart (AlHasan, t.t). This is in contrast to the opinion of Al-Kandahlawi, (1970), he asserted that in fact tarekat and tasawuf are the same thing because tarekat is the second name for Ihsan mentioned in the hadith of Jibril, or tarekat is the path by which one attains the nature of Ihsan. Based on the definition of tarekat by Mawlana Zakaria, it is known that the knowledge of tarekat is also the knowledge of tasawuf.

In addition, looking at the problems related to the understanding of the concept of Sufi order, there are issues that arise related to the discipline of Sufi order that need to be given attention. Among them are the issue of lack of understanding among society (Mahmood, et.al., 2020) and lack of mastery (Stapa, 1999) related to the concept of Sufism which affects to confusion in understanding the discipline of the knowledge (Stapa, 1995). This is because, the discipline of Sufism is also not explained in depth since the beginning of education and it is not in the National Islamic Education syllabus (Stapa, 2012). Not only that, among academicians there are still not many who have done research related to it (Mahmood, et.al., 2020). Thus, looking at the importance of practicing Sufism and the problems that arise, this study aims to identify the relationship between the level of knowledge and perception of the people of Melaka on the concept of Sufi order. It is also to determine the level of knowledge and perception of the people of Melaka on the concept of Sufi order.

\section{Research Methodology}

This study is a survey study involving 385 respondents around the state of Melaka. The study areas involved are Alor Gajah, Melaka Tengah and Jasin districts. Questionnaire instrument was used to obtain data related to the level of knowledge and perception of the people of Melaka on the concept of Sufi order. Correlation analysis is used to determine the relationship between the level of knowledge and perception of the people of Melaka on the concept of Sufi order.

\section{Findings and Discussion}

\section{Level of Knowledge of the Concept of Sufi Order}

Findings for the level of knowledge of respondents on the concept of Sufi order are shown in Table 1. The results showed that 54.5 percent or 210 respondents have a high knowledge of the concept of Sufi order. Meanwhile, a total of 97 respondents or 25.2 percent have a moderate knowledge related to the concept of Sufi order. While 78 respondents or another 20.3 percent felt their level of knowledge was low. The concept of Sufi order was measured using five answer scale options from "strongly not knowing" to "strongly knowing". The 
results of the study found that on average, the respondents' scores for this study were at a moderate level $(M=3.627, S D=1.190)$.

Table 1: Distribution of respondents according to the level of knowledge of respondents on the concept of Sufi order.

\begin{tabular}{llllll}
\hline & & Frequency & Percentage & Min & $\begin{array}{l}\text { Standard } \\
\text { Deviation }\end{array}$ \\
\hline Sufi order & & & & 3.627 & 1.190 \\
Low & $(1.00-2.33)$ & 78 & 20.3 & & \\
Moderate $(2.34-3.67)$ & 97 & 25.2 & & \\
High $(3.68-5.00)$ & 210 & 54.5 & & \\
Total & 385 & 100.0 & & \\
\hline
\end{tabular}

SD: Standard deviation

\section{Perception of the Concept of Sufi order}

Table 2 displays the findings for the level of respondents' perception of the concept of Sufi order. The results showed that 90.4 percent or 348 respondents had a high perception of the concept of Sufi order. Meanwhile, a total of 30 respondents or 7.8 percent have a moderate perception of the concept of Sufi order. While 7 respondents or another 1.8 percent felt their level of perception was low. The concept of Sufi order was measured using five answer scale options from "strongly disagree" to "strongly agree". The results of the study found that on average, the respondents' scores for this study were at a high level $(M=4.221, S D=0.628)$.

Table 2: Distribution of respondents according to the level of perception of respondents towards the Sufi order

\begin{tabular}{lllll}
\hline & Frequency & Percentage & Min & $\begin{array}{l}\text { Standard } \\
\text { Deviation }\end{array}$ \\
\hline Sufi order & & & 4.221 & 0.628 \\
Low $(1.00-2.33)$ & 7 & 1.8 & & \\
Moderate $(2.34-3.67)$ & 30 & 7.8 & & \\
High (3.68-5.00) & 348 & 90.4 & & \\
Total & 385 & 100.0 & & \\
\hline
\end{tabular}

SD: Standard Deviation

Based on the findings in table 1 and table 2, it can be observed that the level of knowledge of respondents on the concept of Sufi order which is at the low level is 78 respondents, but the level of perception at the low level is only 7 respondents. This shows that, although the people of Melaka lack of level of knowledge about the concept of Sufi order, but they have a high and positive perception towards Sufi order.

\section{Correlation Analysis between the Level of Knowledge and Perception of Sufi Order}

Table 3 shows the findings of the correlation analysis. There was a significant positive relationship between knowledge and perception of the concept of Sufi order $(r=0.676, p$ $<0.01)$. Based on the relationship strength by Davis, (1971), the relationship between the knowledge of the Sufi order and the perception of the Sufi order of the respondents is a strong correlation. The positive correlation shows that there is a positive relationship which is, the 
higher the knowledge of the concept of Sufi order, the higher the level of perception of the concept of Sufi order.

Table 3: Correlation of variables and Perceptions of the concept of Sufi order

\begin{tabular}{lll}
\hline Variables & $\boldsymbol{r}$ & $\boldsymbol{p}$ \\
\hline Knowledge of Sufi Order & $.676^{* *}$ & .000 \\
\hline
\end{tabular}

Thus, from the findings displayed in tables 1,2 , and 3 , it can be concluded that the perception of the people of Melaka towards the Sufi order will increase if they are given more exposure to knowledge about it. This is because, in general, the Sufi order is not an inclusiveness that is open among the general public. However, it does not limit the involvement of the public to participate in every activity carried out by each institution of the Sufi order. This is in line with current findings which show that the level of knowledge among the community is at a moderate level.

\section{Conclusion}

This study found that the overall level of knowledge and perception of the concept of Sufi order among the community in the state of Melaka is at a good level. Therefore, as Muslims, it is necessary to further improve the knowledge and understanding related to the Sufi order and makes this discipline as a guide in improving the quality of practice in life. It is hoped that this study can help related parties to have further enhancing efforts in providing understanding to the community related to the discipline of Sufi order.

\section{Acknowledgement}

Appreciation to Kolej Universiti Islam Melaka (KUIM), for granting the Incentive Research Grant 2021: (GPI/21/F1/16) entitled: "Perception of the People of Melaka Towards the Zikir Ceremony in Sufi Order".

\section{References}

Al-Hasan, M. A. (t.t). Khatm al-Awliya'. Beirut: al-Kathulikiyah.

Al-Jurjani, (1985). Al-Ta'rifat. Beirut: Dar al-Kitab al-'Arabi

Al-Kandahlawi, Z. (1970). Al-Syariah wa al-Tariqah. Kaherah: Dar al-Rashid.

Al-Nadwi, A. H. A. (1987). Ketuhanan Bukan Kerahiban: Meluruskan Pemahaman Aliran Tasawuf. Kuala Lumpur: Darul Fikir

Al-Qusyairi, A. K. (1921). al-Risalah al-Qusyairiyah. Kaherah:tp

Al-Taftazani. (1996). Perkembangan Tasawuf Islam. Kuala Lumpur: Bahagian Hal Ehwal Agama Islam Jabatan Perdana Menteri.

As-Syarqawi, H. (1987). Mu'jam al-Alfadhil al-Sufiyah. Kaherah: Muassasah Mukhtar.

Badaruddin, F. (2016). Sejarah asal usul silsilah tarekat tasawuf.Prosiding Seminar Agama dan Pembangunan IX. Bangi: UKM.

Bakri, S., Syaifudin, A. (2019). Sufi Healing Integrasi Tasawuf dan Psikologi Dalam Penyembuhan Psikis dan Fisik. Depok: PT RajaGrafindo Persada.

Davis, J. A. (1971). Elementary survey analysis. Englewood: NJ:Prentice-Hall

Hafiun, M. (2012). Teori Asal Usul Tasawuf. Jurnal Dakwah. Vol 13, No. 2, 241-253.

Harun, M. F. (2015). Tasawuf dan Tarekat Sejarah Perkembangan dan Alirannya di Malaysia. Sintok: Penerbit Universiti Utara Malaysia.

Hilmi, M. M. (1996). Kerohanian dalam Islam. Kuala Lumpur: BAHEIS, JPM. 
Ishak, P. (1993). Ibnu Taimiah: Sejarah Hidup dan Tasawuf. Kuala Lumpur: Dewan Bahasa dan Pustaka.

Mahmood, A. R., Mohamad, A. M., Khairuddin, W. H. (2020). Prosiding Seminar Kebangsaan Asyairah Ahli Sunah Waljamaah 4.0 (SUNNI 2020) Pusat Kajian Usuluddin dan Falsafah, Fakulti Pengajian Islam, Universiti Kebangsaan Malaysia, Bangi, Selangor, 1-17

Azlin, M. A., Badaruddin, F. (2019). Tahap Pengetahuan Masyarakat Terhadap Tarekat di Negeri Sembilan. BITARA International Journal of Civilizational Studies and Human Sciences. 29-26.

Nasution, H. (2008). Falsafat dan Mistisisme Islam. Jakarta: PT Bulan Bintang.

Nasution, Y. (2008). Cakrawala Tasawuf. Jakarta: Putra Grafika.

Riyadi, A. (2014). Tarekat Sebagai Organisasi Tasawuf (Melacak Peran Tarekat Dalam Perkembangan Dakwah Islamiyah). Jurnal al-Taqaddum, 6(2): 359-385.

Rosman, A. S., Abdullah, M. S., Mashrom, M. Z. (2021). Disiplin Ilmu Tarekat Rohani Berasaskan Manhaj Ahlus Sunnah wal Jamaah. Johor Baharu: Jabatan Mufti Johor.

Sidek, J. (2015). Shaikh Dalam Ilmu Tariqah. Selangor: Penerbit al-Falah

Stapa, Z. (1995). Akhlak dan Tasawuf Islam. Kuala Lumpur: Berita Publishing Sdn. Bhd

Stapa, Z. (1999). Tasauf: Menjana Personaliti Umat Abad ke 21. Terengganu: Percetakan Yayasan Islam Terengganu Sdn. Bhd.

Stapa, Z. (2012). Pendekatan Tasawuf dan Tarekat: Wadah Pemerkasaan Jati Diri Ummah. Bangi: Penerbit Universiti Kebangsaan Malaysia.

Sulaiman, U. (2015). Sejarah Kemunculan dan Perkembangan Tasawuf. Tasamuh. Vol. 7 No. $1,1-14$

Syukur, A. \& Masyharudin. (2002). Intelektualisme Tasawuf. Yogyakarta: Pustakan Pelajar dan Lembkota Semarang 